\title{
Selection of Accounting Software for Small and Medium Enterprises Using the Fuzzy Topsis Method
}

\author{
Oleh Vysochan, Olha Vysochan, Alla Yasinska, Vasyl Hyk \\ Lviv Polytechnic National University, Department of Accounting and Analysis, \\ S. Bandery, st., 12, Lviv,79013, Ukraine
}

\begin{abstract}
In the article, the authors analyse the types of accounting software available on the market, in order to identify the most effective programs in terms of meeting the needs of the accounting service of small and medium enterprises. Alternatives for the choice were: large software packages of corporate type, universal programs for automation of financial accounting, programs for the formation and submission of tax reporting, document automation systems, small programs with an emphasis on financial management. The ranking of types of accounting software in terms of compliance with the requirements of accounting services of small and medium enterprises was led by universal programs focused primarily on the implementation of financial accounting functions with maximum support of the accounting process.
\end{abstract}

Keywords - fuzzy TOPSIS method, multicriteria decision making, accounting, accounting software, linguistic variables

\section{Introduction}

Effective accounting is important in all sectors of the institutional environment: from micro-enterprises

DOI: 10.18421/TEM103-43

https://doi.org/10.18421/TEM103-43

Corresponding author: Oleh Vysochan,

Doctor of Economic Sciences, Professor, Department of Accounting and Analysis, Lviv Polytechnic National University, S. Bandery, st., 12, Lviv, Ukraine, 79013.

Email: oleh.s.vysochan@lpnu.ua

Received: 10 February 2021.

Revised: 30 July 2021.

Accepted: 06 August 2021.

Published: 27 August 2021.

(c) BY-NC-ND (C) 2021 Oleh Vysochan et al; published by UIKTEN. This work is licensed under the Creative Commons Attribution-NonCommercial-NoDerivs 4.0 License.

The article is published with Open Access at www.temjournal.com to clusters and international corporations, and from commercial structures to non-budgetary non-profit organizations and public sector entities.

The basic element of such an organization is the establishment of automation of accounting processes in the circuit "primary documentation and assessment of business facts - intermediate generalization of data - final accounting and reporting", as well as expanding accounting functions to solve management and control tasks.

At the same time, automation allows to ensure the completeness of the implementation of the main function of accounting - information, the implementation process of which is presented in [1].

The dynamic development of modern accounting allows us to highlight the following advantages of its automation: ease of identifying values, simplification of asset registers, providing data for scheduling and calculation of financial ratios, providing business with financial information, online accounting (cloud accounting) using the Internet and communication with communication devices, such as smartphones and iPhones, increasing the speed of record processing (for example, by adding a module for the bank manager), expanding opportunities for employment and self-employment, increasing completeness and accuracy [2]. For small and medium enterprises such advantages may be: timely information management, the ability to store large amounts of data, reduce workload and increase productivity, reduce transaction costs and higher quality information, automatic verification of accounts, faster and more accurate data processing and analysis, creating various on-demand reports, automated routine recording processes, better cash management due to increased efficiency of payment and collection processes, providing multi-user access [3].

Automation of accounting in small and medium enterprises has its own characteristics due to the limited financial resources of the latter, the nature of the tasks solved by the accounting system, as well as the presence of additional requirements for the 
efficiency of information, which is associated with highly competitive markets.

Due to their exceptional importance in the economic growth of the country, small and mediumsized businesses should increase their capabilities and practices of using accounting software to win global competition with foreign economic institutions [4]. In Ukraine, the criteria for classifying enterprises as small and medium-sized, according to the Law "On Accounting and Financial Reporting in Ukraine" are: book value of assets - up to 20 million euros; net income from sales of products (goods, works, services) - up to 40 million euros; average number of employees - up to 250 people.

\section{Literature Review and Problem Statement}

One of the initial stages of the accounting automation process is the selection of software relevant to management requests from those available on the Ukrainian market. To do this, it is necessary to establish the criteria for such selection, taking into account all the objective factors influencing the assessment.

In the work of Ch. G. Carpenter, L. A. Le Blanc and G. S. Robson [5], identified were four such criteria: technical, functional, documentation, and vendor information. To choose accounting automation software, A. A. Abu-Musa [6] proposes to take into account the following factors: firm's current needs, firm's future needs, business size, business type, features of accounting software, IT environment and infrastructure and vendor reliability. Determinants of the choice of software for accounting in commercial enterprises, according to O. Muhrtala and M. G. Ogundeji [7], can be the following factors: operational, commercial, technical, security and strategic. Subsequently, the same criteria were used in their studies by E. Yürekli and S. B. Haşiloğlu [8]. In A. S. Jadhav and R. M. Sonar [9], the taxonomy of software evaluation criteria includes seven elements: functional, technical, quality, vendor, output, cost and benefit, and opinion. M. Ramazani, R. Askari and E. Fazli [10], use the ANP method to evaluate accounting software by characteristics: general features, compatibility, flexibility, control, reporting capability and training. In the modern literature there are attempts to adapt the list of requirements for accounting programs to the industry specifics of the business. For example, for small and medium-sized construction companies, Tram and Tuan [11] offer to use the determinants: requirements of users of accounting software, features of accounting software, accounting software providers, cost of using accounting software, support conditions and social influence. To compare the computer accounting software of trade enterprises, L.
R. Paul and L. Sadath [12] use the following criteria: user-friendliness, navigation \& control, reporting function, flexibility, security, customization and vendor support.

The analysis of foreign literature on the outlined topics showed the soundness of scientists' approaches to the selection of nomenclature of criteria for evaluating accounting software, but there is a lack of completed publications on positioning the developed criteria in the coordinate system "firm-supplier initiator of automation - consumer software". In our opinion, the importance of the criteria may be modified depending on the person concerned: an accountant, manager or business owner.

Ukrainian scientists also show a strong interest in the choice of programs for automation of accounting processes in enterprises. The analysis of the possibilities of computer programs for accounting by I. L. Grabchuk and G. I. Lyakhovich [13] is carried out according to the nomenclature of criteria, which, in essence, characterizes the software in terms of functionality and price. A. P. Grinko [14] draws attention to six criteria for selecting the optimal software for automated accounting systems: functional completeness, features of software system construction, principles of adaptation to the peculiarities of accounting work of specific enterprises, the possibility of using on various software-adapted platforms office software of own development or third-party manufacturers and the size of the company's accounting. Generalization of publications of domestic authors allowed A. P. Dykiy and Yu. D. Dovgal [15], as well as O. P. Kolumbet [16] to identify a number of basic criteria for selecting computer accounting programs: the authority of the developer, cost-benefit ratio (efficiency), the degree of versatility, functionality, clarity of the system, user-friendly interface, reliability, software compatibility, technical parameters, level of service, variability, degree of information protection and data control.

Paying tribute to the scientific achievements of modern Ukrainian authors, we should still pay attention to the fragmentary nature of research in their empirical part. Much of the work ends with a list of criteria for evaluating accounting programs without practical confirmation of the reliability of the results.

The generalization of the works of domestic and foreign scientists allows us to identify the following criteria that we will use in the future to assess alternatives for accounting automation in small and medium enterprises:

1) functionality: primary accounting, analytical accounting in terms of different units of measurement, accounting by areas (banking and cash transactions in conjunction with customer-bank 
systems and in different currencies, fixed assets, inventories, production, wages, purchases and sales and etc.), warehouse accounting with the ability to integrate applications to automate the inventory process using barcode readers, work with the log of transactions and / or business transactions, tax accounting with the ability to integrate applications for reporting by electronic means of communication, final accounting according to national and / or international standards, the degree of implementation of management and control functions of accounting, in particular in terms of creating new internal reporting forms;

2) price: it is necessary to estimate not only the cost of acquiring exclusive or non-exclusive rights to use the program, but also the cost of bringing the software to a usable condition (installation costs), as well as additional costs that may arise in the process of such use (update, technical support, purchase of additional services, organization of the security system, recovery of data lost as a result of cyber attacks or system failures);

3) consumer support: availability of methodological literature, user guides, specialized forums on the Internet, efficiency of updating taking into account changes in legislation, the general level of service, in particular, in terms of the seller to customer, extensive network of software and maintenance centers;

4) ease of learning and ease of use: the ability to use the program without prior long training, convenience and intuitive interface, selfconfiguration of typical operations and structure of analytical accounts, the ability to work remotely, compatibility and clarity of data exchange technology with other software packages, trade equipment (if necessary).

The presented study deliberately does not include a group of technical criteria (hardware requirements, features of the software environment, data recovery quality, differentiation of access rights, level of reliability of protection functionality, including protection against user errors, technical staffing, scalability, etc.), because the choice of software is made by experts in the accounting environment, who are the end user of the product, but usually are not experts who can assess the technical tools of the programs.

This list is the basis for assessing the compliance of accounting software to the needs of small and medium enterprises.

At the same time, many socio-economic phenomena are complex, which makes it impossible to describe them in one variable. Evaluation of objects in terms of such phenomena is possible by constructing a synthetic variable that aggregates fragmentary information included in specific criteria, which, in turn, are evaluated linguistically [17]. Statistical analysis, in this case, is impossible without prior work on the transformation of linguistic variables into numerical form (for example, using triangular fuzzy numbers).

\section{The Aim and Objectives of the Study}

The aim of the article is to choose the type of accounting software for small and medium businesses using the Fuzzy TOPSIS Method and taking into account the requests of the accounting department as the end user of the software product.

Objectives of the article:

- development of a set of criteria based on a survey of employees of accounting services of small and medium-sized enterprises to assess the type of accounting software that can most effectively solve the tasks;

- structuring of alternatives available on the market of Ukraine by types of accounting software;

- characteristics of Fuzzy TOPSIS Method as a tool for choosing accounting software, taking into account the multicriteria of such a decision;

- ranking of alternatives from the best to the worst with the assignment of Closeness coefficient depending on the distance to the positive and negative ideal solutions, as provided by Fuzzy TOPSIS technology.

\section{Using the Fuzzy TOPSIS Method to Select the Best Alternative Among Accounting Software Based on a Four-criteria Model}

There are three types of TOPSIS method in scientific publications (Technique for Order of Preference by Similarity to Ideal Solution):

- classic, in which the source data are exact real numbers;

- interval with the original data in the form of intervals that have a minimum value as the beginning of the interval and a maximum as its end;

- fuzzy, in which the original data are expressed using linguistic variables [18].

TOPSIS is a well-known method for multi-criteria decision making (MCDM), which was proposed in 1981 by Hwang and Yoon [19] and is widely used in modern economic research. The Fuzzy TOPSIS method is based on positive fuzzy triangular numbers and was developed by Chen in 2000 [20] to enhance the capabilities of traditional TOPSIS.

The basic logic of TOPSIS methods is to establish a positive ideal solution (PIS) that maximizes the benefit criteria and minimizes the cost criteria and a 
negative ideal solution (NIS) that minimizes the benefit criteria and maximizes the cost criteria. The optimal alternative is the one that provides the closest distance from the positive decision and, accordingly, the farthest distance from the negative decision [21].

The Fuzzy TOPSIS method for evaluating accounting automation software in small and medium-sized businesses is implemented sequentially performing the following steps:

Step 1. Establish a scale of linguistic variables to evaluate software and convert it into a set of fuzzy numbers.

Since the selection of optimal software for the enterprise is a complex, poorly structured problem, the solution of which involves taking into account the influence of factors that cannot be quantified, it is useful to use linguistic variables to describe the evaluation criteria of accounting programs (Table 1.).

Table 1. Fuzzy Scale

\begin{tabular}{|c|c|c|c|c|}
\hline Code & Linguistic terms & L & M & U \\
\hline 1 & Very weak & 0 & 1 & 3 \\
\hline 2 & Weak & 1 & 3 & 5 \\
\hline 3 & Average & 3 & 5 & 7 \\
\hline 4 & Good & 5 & 7 & 9 \\
\hline 5 & Very good & 7 & 9 & 10 \\
\hline
\end{tabular}

Thus, the scale of a fuzzy number (membership function) is determined by its three parameters.

Fig. 1. presents a graphical representation of positive triangular fuzzy numbers for the characteristics of linguistic terms used as evaluation criteria for accounting automation software in small and medium enterprises.

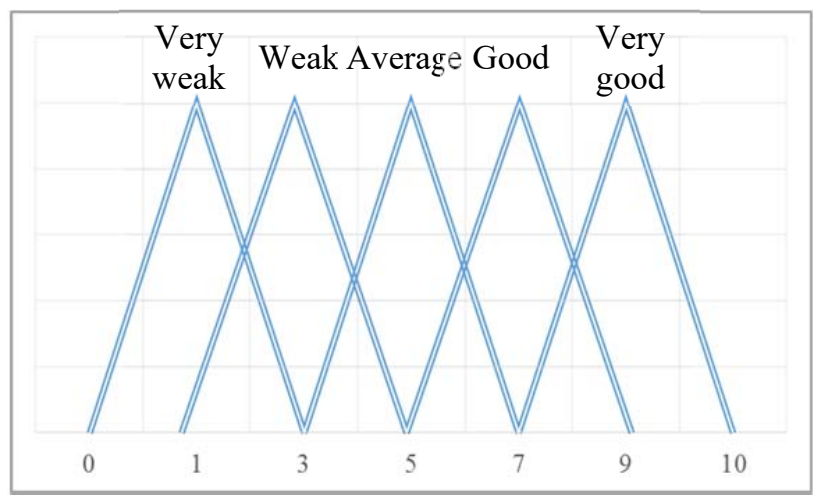

Figure 1. Linguistic terms converted into fuzzy numbers (5-point scale)

The positive triangular fuzzy number $\tilde{F}$ is set as follows (1) (based on [22]):

$$
\tilde{F}=\left(a_{\tilde{F}}, b_{\tilde{F}}, c_{\tilde{F}}\right)
$$

where, $a_{\tilde{F}}-$ lower limit of fuzzy number;

$b_{\tilde{F}}$ - peak point (middle) of a fuzzy number, which characterizes the most probable value of the estimated value;
$c_{\tilde{F}}$ - the upper limit of a fuzzy number.

$a_{\tilde{F}}, b_{\tilde{F}}, c_{\tilde{F}}$ are real numbers and the condition is satisfied $0 \leq a_{\tilde{F}} \leq b_{\tilde{F}} \leq c_{\tilde{F}}$.

Preferably, the positions of the parameters $a_{\tilde{F}}$ and $c_{\tilde{F}}$ are symmetric with respect to the value of $b_{\tilde{F}}$. This means that the membership function usually creates an isosceles triangle [23]. At the same time, in some cases different sides of the triangle are possible (the first and last triangles in Fig. 1.).

The constants $a_{\tilde{F}}$ and $c_{\tilde{F}}$ are the lower and upper limits of the available range for the estimated data. These constants show the vagueness of the data for evaluation. The narrower the interval $\left[a_{\tilde{F}}, c_{\tilde{F}}\right]$, the lower the level of vagueness of the estimated data [24].

The membership function of a triangular fuzzy number $\mu_{\tilde{F}}(x)$ is formalized as follows (2):

$$
\mu_{\tilde{F}}(x)=\left\{\begin{array}{l}
\frac{x-a_{\widetilde{F}}}{b_{\widetilde{F}}-a_{\widetilde{F}}} \text { or }_{\tilde{F}} \leq x \leq b_{\tilde{F}} \\
\frac{c_{\widetilde{F}}-x}{c_{\widetilde{F}}-b_{\widetilde{F}}} \text { for } b_{\tilde{F}} \leq x \leq c_{\tilde{F}}
\end{array}\right.
$$

Step 2. Preparation of data on the degree of compliance of the alternative version of the accounting software group with each of the selected criteria.

The set of alternatives is a matrix $A=$ $\left(A_{1}, A_{2}, A_{3}, A_{4}, A_{5}\right)$, which contains information about groups of accounting software, each of which is evaluated by a number of criteria (Table 2.).

Table 2. Characteristics of variants of realization of tasks of automation of accounting processes at the enterprises

\begin{tabular}{|l|l|}
\hline $\begin{array}{c}\text { Implementation } \\
\text { option }\end{array}$ & \multicolumn{1}{|c|}{ Characteristic } \\
\hline alternative1 $\left(\mathrm{A}_{1}\right)$ & $\begin{array}{l}\text { Software for automation of basic } \\
\text { functions of enterprise management, } \\
\text { incl. management accounting, } \\
\text { controlling and accounting according } \\
\text { to international standards }\end{array}$ \\
\hline alternative2 $\left(\mathrm{A}_{2}\right)$ & $\begin{array}{l}\text { Applications for accounting } \\
\text { automation for all basic areas with the } \\
\text { ability to integrate additional modules }\end{array}$ \\
\hline alternative3 $\left(\mathrm{A}_{3}\right)$ & $\begin{array}{l}\text { Decisions aimed at tax accounting in } \\
\text { online format usually using cloud } \\
\text { technologies and reporting by } \\
\text { electronic means to regulatory } \\
\text { authorities }\end{array}$ \\
\hline alternative4 $\left(\mathrm{A}_{4}\right)$ & $\begin{array}{l}\text { Solutions for full automation of } \\
\text { document flow with subsequent export } \\
\text { of data to well-known commonly used } \\
\text { applications }\end{array}$ \\
\hline alternative5 $\left(\mathrm{A}_{5}\right)$ & $\begin{array}{l}\text { Programs aimed at financial } \\
\text { management with accounting as an } \\
\text { ancillary function }\end{array}$ \\
\hline
\end{tabular}

Based on the opinion of experts and bibliographic analysis, 4 main criteria were chosen, according to which the choice of accounting software is made: $\mathrm{C}^{1}$ 
$=$ functionality; $\mathrm{C}^{2}=$ price (license cost and additional maintenance costs); $\mathrm{C}^{3}=$ consumer consulting and technical support; $\mathrm{C}^{4}=$ ease of learning and ease of use of the program (Table 3.).

Table 3. Brief description of the criteria for evaluating the accounting software of small and medium enterprises

\begin{tabular}{|c|c|c|c|c|}
\hline \multirow{2}{*}{ 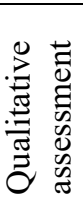 } & \multicolumn{4}{|c|}{ Criteria } \\
\hline & Functionality & Price & $\begin{array}{c}\text { Consumer } \\
\text { support }\end{array}$ & 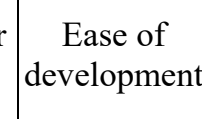 \\
\hline $\begin{array}{l}7 \\
8 \\
0 \\
0 \\
2 \\
2 \\
>0\end{array}$ & $\begin{array}{l}\text { Providing full } \\
\text { functionality, the } \\
\text { possibility of its } \\
\text { optimization, the } \\
\text { availability of } \\
\text { tools to simplify } \\
\text { accounting } \\
\text { work, the } \\
\text { implementation } \\
\text { of additional } \\
\text { services: Internet } \\
\text { banking, } \\
\text { downloading } \\
\text { exchange rates, } \\
\text { etc. }\end{array}$ & Free & $\begin{array}{l}\text { Personal } \\
\text { qualified } \\
\text { consultant } \\
\text { from the } \\
\text { developer } \\
\text { or seller, } \\
\text { quick } \\
\text { response } \\
\text { to the } \\
\text { request }\end{array}$ & $\begin{array}{l}\text { Easy to } \\
\text { manage } \\
\text { "intuitive" } \\
\text { software }\end{array}$ \\
\hline $\begin{array}{l}\text { Tु } \\
8 \\
0\end{array}$ & $\begin{array}{l}\text { All areas of } \\
\text { accounting are } \\
\text { implemented at a } \\
\text { high } \\
\text { methodological } \\
\text { level, the } \\
\text { possibility of } \\
\text { constant } \\
\text { updating of } \\
\text { conditional static } \\
\text { information, } \\
\text { implemented } \\
\text { measures of } \\
\text { arithmetic and } \\
\text { logical control }\end{array}$ & $\begin{array}{l}\text { Free } \\
\text { with a } \\
\text { small } \\
\text { annual } \\
\text { subscri } \\
\text { ption } \\
\text { fee }\end{array}$ & $\begin{array}{l}\text { Possibility } \\
\text { of direct } \\
\text { communic } \\
\text { ation with } \\
\text { the } \\
\text { consultant, } \\
\text { fast } \\
\text { eliminatio } \\
\text { n of } \\
\text { technical } \\
\text { problems, } \\
\text { availabilit } \\
\text { y of } \\
\text { effective } \\
\text { means of } \\
\text { communic } \\
\text { ation } \\
\text { (chat, e- } \\
\text { mail) }\end{array}$ & $\begin{array}{l}\text { Clear } \\
\text { interface, } \\
\text { ease of use, } \\
\text { the presence } \\
\text { of an } \\
\text { electronic } \\
\text { assistant }\end{array}$ \\
\hline 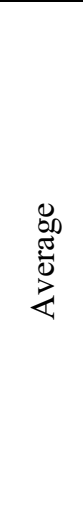 & $\begin{array}{l}\text { The presence of } \\
\text { redundant } \\
\text { software } \\
\text { functionality for } \\
\text { the enterprise, } \\
\text { the complexity } \\
\text { of integrating } \\
\text { additional } \\
\text { modules into the } \\
\text { system at the } \\
\text { request of the } \\
\text { user }\end{array}$ & $\begin{array}{l}\text { Up to } \\
\text { UAH } \\
10000 \\
\text { for the } \\
\text { basic } \\
\text { complet } \\
\text { e set }\end{array}$ & $\begin{array}{l}\text { Profession } \\
\text { al service } \\
\text { is enough, } \\
\text { but the } \\
\text { speed of } \\
\text { response } \\
\text { to the } \\
\text { request is } \\
\text { low }\end{array}$ & $\begin{array}{l}\text { The } \\
\text { interface is } \\
\text { intuitive, but } \\
\text { working } \\
\text { with the } \\
\text { program is } \\
\text { complicated } \\
\text { by a } \\
\text { significant } \\
\text { number of } \\
\text { unnecessary } \\
\text { manipulatio } \\
\text { ns }\end{array}$ \\
\hline
\end{tabular}

\begin{tabular}{|c|c|c|c|c|}
\hline$\frac{y}{\tilde{J}}$ & $\begin{array}{l}\text { Possibility of } \\
\text { submitting tax } \\
\text { reports by } \\
\text { electronic } \\
\text { means, but lack } \\
\text { of automated } \\
\text { generation of } \\
\text { financial } \\
\text { statements, some } \\
\text { areas of } \\
\text { accounting are } \\
\text { partially } \\
\text { automated }\end{array}$ & $\begin{array}{l}\text { UAH } \\
10000 \\
- \text { UAH } \\
100000 \\
\text { for } \\
\text { purchas } \\
\text { ing a } \\
\text { license }\end{array}$ & $\begin{array}{l}\text { The user } \\
\text { does not } \\
\text { receive a } \\
\text { quality } \\
\text { response } \\
\text { to the } \\
\text { request, } \\
\text { lack of } \\
\text { direct } \\
\text { communic } \\
\text { ation with } \\
\text { the } \\
\text { consultant, } \\
\text { inappropri } \\
\text { ate } \\
\text { redirection } \\
\text { of requests }\end{array}$ & $\begin{array}{l}\text { Working } \\
\text { with the } \\
\text { program } \\
\text { requires } \\
\text { long-term } \\
\text { preparation } \\
\text { with the } \\
\text { involvement } \\
\text { of external } \\
\text { consultants }\end{array}$ \\
\hline $\begin{array}{l}\frac{y}{\vec{J}} \\
0 \\
3 \\
\overrightarrow{0} \\
\overrightarrow{0}\end{array}$ & $\begin{array}{l}\text { Accounting is } \\
\text { implemented at } \\
\text { the level of } \\
\text { document flow, } \\
\text { manual data } \\
\text { aggregation, no } \\
\text { double entry in } \\
\text { accounting } \\
\text { transactions }\end{array}$ & $\begin{array}{l}\text { From } \\
\text { UAH } \\
100000 \\
\text { with } \\
\text { addition } \\
\text { al costs } \\
\text { for } \\
\text { adjustin } \\
\text { g the } \\
\text { progra } \\
\text { m to the } \\
\text { specific } \\
\text { s of the } \\
\text { enterpri } \\
\text { se }\end{array}$ & $\begin{array}{l}\text { Lack of } \\
\text { qualified } \\
\text { support } \\
\text { from the } \\
\text { software } \\
\text { developer } \\
\text { and / or } \\
\text { developer }\end{array}$ & $\begin{array}{l}\text { For effective } \\
\text { operation it } \\
\text { is necessary } \\
\text { to take } \\
\text { special } \\
\text { courses, } \\
\text { knowledge } \\
\text { of the basics } \\
\text { of } \\
\text { programmin } \\
\text { g }\end{array}$ \\
\hline
\end{tabular}

These criteria are in the nature of advantage (functionality, support of observation, ease of development) and cost (price), which, in turn, affects the establishment of the ideal solution: maximizing values for career advantage and minimizing - for the criterion of costs.

Step 3. Establish a set of weights for each of the criteria.

The vector of weighting criteria looks like this (3):

$$
w=\left(w_{1}, w_{2}, w_{3}, w_{4}\right)
$$

whe $w_{j}$-weight criterion.

re,

$$
w_{j} \in[0,1], \text { a } \sum_{j=1}^{4} w_{j}=1
$$

The weights transformed to work with fuzzy numbers are presented in Table 4.

Table 4. Characteristics of criteria

\begin{tabular}{|c|c|c|}
\hline Name & Type & Weight $\left(\widetilde{w}_{j}\right)$ \\
\hline Functionality & + & $(0.350,0.350,0.350)$ \\
\hline Price & - & $(0.200,0.200,0.200)$ \\
\hline Support & + & $(0.250,0.250,0.250)$ \\
\hline Mastering & + & $(0.200,0.200,0.200)$ \\
\hline
\end{tabular}

The type identifies the criteria of benefits ("+") and costs ("-"). 
Step 4. Setting the decision matrix.

The results of the evaluation of 5 alternatives $(i=1,2,3,4,5)$ according to 4 criteria $(j=1,2,3,4)$ are displayed in the form of a matrix (4):

$$
X=\left(x_{i j}\right)=\left(\begin{array}{l}
x_{11} x_{12} x_{13} x_{14} \\
x_{21} x_{22} x_{23} x_{24} \\
x_{31} x_{32} x_{33} x_{34} \\
x_{41} x_{42} x_{43} x_{44} \\
x_{51} x_{52} x_{53} x_{54}
\end{array}\right)
$$

Since many experts are involved in the evaluation of alternatives, the matrix presents the arithmetic mean of the estimates of all experts, without taking into account their qualifications and other related factors.

Step 5. Linear normalization of the decision matrix.

Normalization is necessary to bring the values of the decision matrix to a single scale to ensure the possibility of their comparison and it is carried out by formula (5):

$\left\{\left(\frac{a_{i j}}{c_{j}^{+}}, \frac{b_{i j}}{c_{j}^{+}}, \frac{c_{i j}}{c_{j}^{+}}\right) ; c_{j}^{+}=\max _{i} c_{i j}\right.$ for positive ideal solution

$$
\tilde{r}_{i j}=
$$$$
\left\{\left(\frac{a_{j}^{-}}{c_{i j}}, \frac{a_{j}^{-}}{b_{i j}}, \frac{a_{j}^{-}}{a_{i j}}\right) ; a_{j}^{-}=\min _{i} a_{i j}\right. \text { for negative ideal solution }
$$

Step 6. Creating a weighted normalized decision matrix.

The main goal in this step is to modify the normalized solution matrix taking into account the different weights of each criterion (6):

$$
\tilde{v}_{i j}=\tilde{r}_{i j} * \widetilde{w}_{i j}
$$

where, $\widetilde{w}_{i j}$ - weight criterion $\mathrm{c}_{j}$.

Step 7. Establish a fuzzy positive ideal solution $\left(F_{P I S}, A^{+}\right)$and a fuzzy negative ideal solution $\left(F_{N I S}, A^{-}\right)$.

Fuzzy ideal solutions are defined as (7) - (8):

$$
\begin{gathered}
A^{+}=\left\{\tilde{v}_{1}^{+}, \tilde{v}_{2}^{+}, \tilde{v}_{3}^{+}, \tilde{v}_{4}^{+}, \tilde{v}_{5}^{+}\right\}= \\
\left\{\left(\max _{j} v_{i j} \mid i \in B\right),\left(\min _{j} v_{i j} \mid i \in C\right)\right\} \\
A^{-}=\left\{\tilde{v}_{1}^{-}, \tilde{v}_{2}^{-}, \tilde{v}_{3}^{-}, \tilde{v}_{4}^{-}, \tilde{v}_{5}^{-}\right\}= \\
\left\{\left(\min _{j} v_{i j} \mid i \in B\right),\left(\max _{j} v_{i j} \mid i \in C\right)\right\}
\end{gathered}
$$

where, $\tilde{v}_{i}^{+}$-maximum score $i$ for all alternatives;

$\tilde{v}_{i}^{-}$- minimum score $i$ for all alternatives;

$B$ - positive ideal solutions;

$C$ - negative ideal solutions.

Step 8. Calculate the distance between each alternative and the fuzzy positive ideal solution, as well as each alternative and the fuzzy negative ideal solution.

The distance between alternatives and ideal solutions (both positive and negative) is set by formulas (9) - (10):

$$
S_{i}^{+}=\sum_{j=1}^{4} d\left(\tilde{v}_{i j}, \tilde{v}_{j}^{+}\right), i=1,2,3,4,5
$$

$$
S_{i}^{-}=\sum_{j=1}^{4} d\left(\tilde{v}_{i j}, \tilde{v}_{j}^{-}\right), i=1,2,3,4,5
$$

where, $d$ - the distance between two fuzzy numbers.

In this case, $d\left(\tilde{v}_{i j}, \tilde{v}_{j}^{+}\right)$and $d\left(\tilde{v}_{i j}, \tilde{v}_{j}^{-}\right)$are clear numbers.

For two triangular fuzzy numbers $\widetilde{M}_{1}=$ $\left(a_{1}, b_{1}, c_{1}\right)$ and $\widetilde{M}_{2}=\left(a_{2}, b_{2}, c_{2}\right)$ the distance $\mathrm{d}$ is defined as (11):

$$
\sqrt{\frac{1}{3}\left[\left(a_{1}-a_{2}\right)^{2}+\left(b_{1}-b_{2}\right)^{2}+\left(c_{1}-c_{2}\right)^{2}\right]}
$$

Step 9. Calculation of closeness coefficient and ranking of alternatives.

The closeness coefficient is calculated for each compared alternative as the ratio of the distance calculated for it from the ideal worst solution to the sum of the distances to the best and worst solutions [25]. Thus, the efficiency index of alternatives $\left(C C_{i}\right)$, on the basis of which the rating of alternatives is formed, is calculated by formula (12):

$$
0 \leq C C_{i} \leq 1
$$

The best alternative is closer to a fuzzy positive ideal solution and farther from a fuzzy negative ideal solution, so it has the greatest value of closeness coefficient.

\section{The Results of the Decision to Select the best Software for Accounting Automation in Small and Medium Enterprises by the Method of Fuzzy TOPSIS}

To automate the calculations in the implementation of the multi-criteria model of decision-making on the choice of accounting software in our study used the software service Fuzzy TOPSIS by Online Output Softwares.

The starting point for finding the best alternative type of software for accounting in small and medium enterprises is to build a decision matrix, which consists of ratings in the form of triangular fuzzy numbers obtained from a survey of 48 respondents accountants of Ukrainian enterprises (Table 5.).

Table 5. Decision Matrix

\begin{tabular}{|c|c|c|c|c|}
\hline $\begin{array}{c}\text { Alterna } \\
\text { tives }\end{array}$ & $\begin{array}{c}\text { Functionalit } \\
\mathrm{y}\end{array}$ & Price & Support & Mastering \\
\hline alternat & $(4.333,6.33$ & $(0.000,1.000$, & $(3.667,5.66$ & $(0.667,2.33$ \\
ive1 & $3,8.333)$ & $3.000)$ & $7,7.667)$ & $3,4.333)$ \\
\hline alternat & $(6.333,8.33$ & $(4.333,6.333$, & $(5.667,7.66$ & $(3.667,5.66$ \\
ive2 & $3,9.667)$ & $8.333)$ & $7,9.333)$ & $7,7.667)$ \\
\hline alternat & $(3.000,5.00$ & $(5.667,7.667$, & $(0.667,2.33$ & $(3.667,5.66$ \\
ive3 & $0,7.000)$ & $9.333)$ & $3,4.333)$ & $7,7.667)$ \\
\hline alternat & $(0.667,2.33$ & $(5.667,7.667$, & $(0.333,1.66$ & $(5.667,7.66$ \\
ive4 & $3,4.333)$ & $9.333)$ & $7,3.667)$ & $7,9.333)$ \\
\hline alternat & $(0.000,1.00$ & $(7.000,9.000$, & $(0.000,1.00$ & $(5.667,7.66$ \\
ive5 & $0,3.000)$ & $10.000)$ & $0,3.000)$ & $7,9.333)$ \\
\hline
\end{tabular}


Thus, we have five possible alternatives to the types of software for automating accounting processes, evaluated by four criteria in the form of triangular fuzzy numbers.

The results of the expert assessment are normalized to bring them to a scale from 0 to 1 (Table 6.).

Table 6. A normalized decision matrix

\begin{tabular}{|c|c|c|c|c|}
\hline $\begin{array}{c}\text { Altern } \\
\text { atives }\end{array}$ & $\begin{array}{c}\text { Functionali } \\
\text { ty }\end{array}$ & Price & Support & Mastering \\
\hline $\begin{array}{c}\text { alterna } \\
\text { tive1 }\end{array}$ & $\begin{array}{c}(0.448,0.65 \\
5,0.862)\end{array}$ & $(0.000,0.10$ & $(0.393,0.60$ & $0.071,0.25$ \\
\hline alterna & $(0.655,0.86$ & $(0.433,0.63$ & $(0.607,0.82$ & $(0.393,0.60$ \\
tive2 & $2,1.000)$ & $3,0.833)$ & $1,1.000)$ & $7,0.821)$ \\
\hline alterna & $(0.310,0.51$ & $(0.567,0.76$ & $(0.071,0.25$ & $(0.393,0.60$ \\
tive3 & $7,0.724)$ & $7,0.933)$ & $0,0.464)$ & $7,0.821)$ \\
\hline alterna & $(0.069,0.24$ & $(0.567,0.76$ & $(0.036,0.17$ & $(0.607,0.82$ \\
tive4 & $1,0.448)$ & $7,0.933)$ & $9,0.393)$ & $1,1.000)$ \\
\hline $\begin{array}{c}\text { alterna } \\
\text { tive5 }\end{array}$ & $(0.000,0.10$ & $(0.700,0.90$ & $(0.000,0.10$ & $0.607,0.82$ \\
\hline
\end{tabular}

The sixth step of the analysis is to find a weighted matrix of fuzzy solutions, which in our case looks like this (Table 7.).

Table 7. The weighted normalized decision matrix

\begin{tabular}{|c|c|c|c|c|}
\hline $\begin{array}{c}\text { Altern } \\
\text { atives }\end{array}$ & $\begin{array}{c}\text { Functionali } \\
\text { ty }\end{array}$ & Price & Support & Mastering \\
\hline alterna & $(0.157,0.22$ & $(0.000,0.02$ & $(0.098,0.15$ & $(0.014,0.05$ \\
tive1 & $8,0.302)$ & $0,0.060)$ & $2,0.205)$ & $0,0.093)$ \\
\hline alterna & $(0.229,0.30$ & $(0.087,0.12$ & $(0.152,0.20$ & $(0.079,0.12$ \\
tive2 & $2,0.350)$ & $7,0.167)$ & $5,0.250)$ & $1,0.164)$ \\
\hline alterna & $(0.109,0.18$ & $(0.113,0.15$ & $(0.018,0.06$ & $(0.079,0.12$ \\
tive3 & $1,0.253)$ & $3,0.187)$ & $2,0.116)$ & $1,0.164)$ \\
\hline alterna & $(0.024,0.08$ & $(0.113,0.15$ & $(0.009,0.04$ & $0.121,0.16$ \\
tive4 & $4,0.157)$ & $3,0.187)$ & $5,0.098)$ & $4,0.200)$ \\
\hline alterna & $(0.000,0.03$ & $(0.140,0.18$ & $(0.000,0.02$ & $(0.121,0.16$ \\
tive5 & $6,0.109)$ & $0,0.200)$ & $7,0.080)$ & $4,0.200)$ \\
\hline
\end{tabular}

Setting benchmarks for fuzzy positive ideal solution $\left(F_{P I S}\right)$ and fuzzy negative ideal solution $\left(F_{N I S}\right)$ is to set triangular fuzzy numbers $(\mathrm{A}+)$ and $(A-)$, respectively (Table 8.), which is the seventh step of Fuzzy TOPSIS analysis.

Table 8. The positive and negative ideal solutions

\begin{tabular}{|c|c|c|}
\hline Criteria & Positive ideal & Negative ideal \\
\hline Functionality & $(0.229,0.302,0.350)$ & $(0.000,0.036,0.109)$ \\
\hline Price & $(0.140,0.180,0.200)$ & $(0.000,0.020,0.060)$ \\
\hline Support & $(0.152,0.205,0.250)$ & $(0.000,0.027,0.080)$ \\
\hline Mastering & $(0.121,0.164,0.200)$ & $(0.014,0.050,0.093)$ \\
\hline
\end{tabular}

To assess the level of similarity of the alternative with the ideal solution, the distances to both negative and positive ideal solutions should be calculated (Table 9.).
Table 9. Distance from positive and negative ideal solutions

\begin{tabular}{|c|c|c|}
\hline Alternatives & $\begin{array}{c}\text { Distance from } \\
\text { positive ideal }\end{array}$ & $\begin{array}{c}\text { Distance from } \\
\text { negative ideal }\end{array}$ \\
\hline alternative1 & 0.373 & 0.299 \\
\hline alternative2 & 0.088 & 0.582 \\
\hline alternative3 & 0.314 & 0.359 \\
\hline alternative4 & 0.380 & 0.292 \\
\hline alternative5 & 0.413 & 0.257 \\
\hline
\end{tabular}

Proximity to the ideal solution is characterized by the distance indicator - the lower the indicator, the better the alternative in terms of previously selected criteria.

The closeness coefficient is calculated by equation (12) taking into account the total distance from the ideal value. According to the calculated coefficient, the software is ranked in terms of alternatives, from which the best of the five available is selected (Table 10.).

Table 10. Closeness coefficient

\begin{tabular}{|c|c|c|}
\hline Alternatives & ${ }_{i} C C$ & rank \\
\hline alternative1 & 0.445 & 3 \\
\hline alternative2 & 0.868 & 1 \\
\hline alternative3 & 0.533 & 2 \\
\hline alternative4 & 0.434 & 4 \\
\hline alternative5 & 0.383 & 5 \\
\hline
\end{tabular}

In essence, the Closeness coefficient sets the level of satisfaction with the i-th alternative compared to the ideal solution.

\section{Discussion of the Results of Using the Fuzzy TOPSIS Method to Establish the Optimal Type of Accounting Software for SMEs}

According to the results in Table 10., the rating of types of accounting software in terms of compliance with the requirements of accounting services of small and medium enterprises of Ukraine is as follows: alternative2 $>$ alternative3 $>$ alternative1 $>$ alternative $4>$ alternative5 (Fig. 2.).

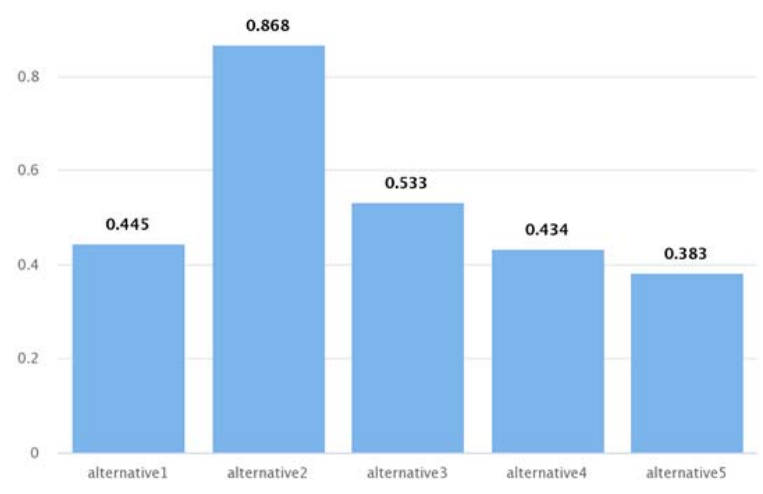

Figure 2. Closeness coefficient graph 
According to the current study, the most effective type of accounting software for the small and medium business sector are universal accounting systems with full automation of all areas of financial accounting, but with a number of limitations in meeting the needs of management accounting and control (alternative2). Small businesses are considering the use of automated systems focused solely on tax accounting (alternative3), but the limited scale and lack of fully automated financial accounting seriously hinder the use of such systems in medium-sized enterprises. The high cost of large management systems of Enterprise Resource Planning (alternative1) prevents their use in the medium business segment, but can be considered in terms of strategic prospects for enterprise development. Low cost, and sometimes no payment for the use of small application packages (alternative4, alternative5), does not help to remove them from the category of outsiders due to the significant limited functionality. Such programs can be used by micro-enterprises, while small and medium-sized enterprises operate them only in conjunction with high-end accounting software, which can create compatibility issues.

The expert assessment of accountants of small and medium enterprises, which we used in the study, provides the necessary level of confidence in the results, as it is based on the opinion and requirements of end users of the software product despite a number of technical and strategic factors. Extending the scope of the study to include system administrators (to assess technical factors) and senior managers (to assess strategic prospects) among the expert respondents may seem to increase its practical value, but in our view, there are risks of conflicts of interest between interested groups of persons.

\section{Conclusions}

1. The size of the enterprise and the correlated indicator of the size of the accounting service are factors that influence the choice of accounting software - small and medium enterprises of Ukraine prefer simple, flexible, relatively inexpensive developments, which are "sharpened" for financial accounting tasks. in contrast to large, branched business structures that seek to use systems with integrated functions of management accounting, control and strategic management.

2. Fuzzy TOPSIS is an effective method for multicriteria assessment of decision-making in various socio-economic spheres of knowledge. To select the optimal type of software for automation of accounting processes, the following criteria are set: functionality; price (license cost and additional maintenance costs); consumer consulting and technical support; ease of learning and ease of use of the program. The importance of each of them is determined by the needs of the accountant as the end user of the software product. The choice is made from five alternatives, each of which outlines a certain type of software available on the Ukrainian market.

3. The use of fuzzy type TOPSIS method is dictated by the difficulty of a clear numerical assessment of the selection criteria of accounting software, which makes it necessary to display the original data using linguistic variables. Even the price criterion cannot be precisely determined numerically, as it includes poorly predicted parameters, such as the cost of recovering data lost as a result of possible cyberattacks or system failures.

4. The best alternative for small and medium enterprises of Ukraine is to use application automation programs for all basic areas with the possibility of integrating additional modules (alternative 2, CCi $=0.868$ ), which is explained by the maximum implementation of accounting tasks in all areas and the optimal ratio of functionality and price. Many small businesses also prefer the autonomous use of automated tax accounting systems (alternative 3, CCi $=0.533$ ), thus limiting themselves to the information capabilities provided by the financial accounting system. At the same time, expensive management information systems (alternative 1, CCi $=0.445$ ) seek to use mediumsized enterprises whose activities are aimed at expanding markets and strategic development.

\section{References}

[1]. Vysochan, O. S. and Kish, I. R. (2016). Transformation of the information function of accounting as a response to the challenges of the contemporary economics. Business Inform, 3, 160165.

[2]. Machera, R. P., \& Machera, P. C. (2017). Computerised Accounting Software; A Curriculum That Enhances an Accounting Programme. Universal journal of educational research, 5(3), 372-385. https://doi.org/10.13189/ujer.2017.050310.

[3]. Udegbunam, E. O., Uchenu, C. A., Odimmega, C. G., \& Nwogu, M. C. (2017). Electronic Accounting A Tool for Quality Management of Small and Medium Scale Enterprises (Smes) in the 21st Century Nigeria. Nigerian Journal of Business Education (NIGJBED), 5(2), 86-95.

[4]. Rahman, M. M., Elahi, T., Gupta, S., \& Rahman, I. (2014). Assessment of Accounting Software Practices in Small Medium Enterprises (SMEs) of Bangladesh: A Survey of Barrier and Adoption (Dhaka City). International Journal of Management Sciences and Business Research, 3(4).

[5]. Carpenter, C. G., Le Blanc, L. A., \& Robson, G. S. (2005). Fixed Asset Accounting Software Evaluation: A Structured Methodology For The Mid-Market Firm. Review of Business Information Systems (RBIS), 9(2), 55-68. 
[6]. Abu-Musa, A. A. (2005). The determinates of selecting accounting software: A proposed model. Review of Business Information Systems (RBIS), 9(3), 85-110. https://doi.org/10.19030/rbis.v9i3.4456.

[7]. Muhrtala, O., \& Ogundeji, M. G. (2014). Determinates of Accounting Software Choice: An Empirical Approach. Universal Journal of Accounting and Finance, 2(1), 24-31. https://doi.org/10.13189/ujaf.2014.020103.

[8]. Yürekli, E., \& Haşiloğlu, S. B. (2017). Evaluation of the factors affecting the purchasing decisions of accounting package programs. Journal of Internet Applications and Management, 8(1), 47-64. https://doi.org/10.5505/iuyd.2017.46330.

[9]. Jadhav, A. S., \& Sonar, R. M. (2011). Framework for evaluation and selection of the software packages: A hybrid knowledge based system approach. Journal of Systems and Software, 84(8), 1394-1407. https://doi.org/10.1016/j.jss.2011.03.034.

[10]. Ramazani, M., Askari, R., \& Fazli, E. (2014). Application of ANP in Evaluating Accounting Softwares based on Accounting Information Systems Characteristics. Journal of Emerging Trends in Computing and Information Sciences, 5(5).

[11]. Tram, N. T. H. and Tuan, L. A. (2019). Researching the selection of accounting software for small and medium construction enterprises in Ho Chi Minh City. International Journal of Innovative Science and Research Technology, 4(12), 418-427.

[12]. Paul, L. R., \& Sadath, L. (2019, December). Choosing the Right Accounting Software for Organised Retail Environment. In 2019 International Conference on Computational Intelligence and Knowledge Economy (ICCIKE) (pp. 505-510). IEEE.

[13]. Grabchuk, I. L. and Lyakhovich, G. I. (2017). Software for Conducting Accounting: Problems of Choice and Use in the Course of Outsourcing. Problems of Theory and Methodology of Accounting, Control and Analysis, 3 (38), 32-36. http://dx.doi.org/10.26642/pbo-2017-3(38)-32-36.

[14]. Grinko, A. P. (2009). Criteria for selecting software for automated fixed assets accounting system. Economic Strategy and Perspectives of the Development of Trade and Services Sphere, 2(10), 187-193.
[15]. Dykiy, A. P. and Dovgal, Yu. D. (2008). Peculiarities of choosing computer software for accounting computerization at large-scale enterprises. The Journal of Zhytomyr State Technological University. Series: Economics, 46(4), 61-70.

[16]. Kolumbet, O. P. (2014). Implementation of computerized accounting information systems: features and sequence of implementation. Accounting, Analysis and Audit: Problems of Theory, Methodology, Organization: Collection of Scientific Works, 2, 107-115.

[17]. Dudek, A., \& Jefmański, B. (2015). The fuzzy TOPSIS method and its implementation in the $\mathrm{R}$ programme. Informatyka Ekonomiczna, (1 (35)), 1927. https://doi.org/10.15611/ie.2015.1.02.

[18]. Kobryń, A., \& Prystrom, J. (2016). A data preprocessing model for the Topsis method. Folia Oeconomica Stetinensia, 16(2), 219. https://doi.org/10.1515/foli-2016-0036.

[19]. Hwang, C. L., \& Yoon, K. (1981). Methods for multiple attribute decision making. In Multiple attribute decision making (pp. 58-191). Springer, Berlin, Heidelberg.

[20]. Chen, C. T. (2000). Extensions of the TOPSIS for group decision-making under fuzzy environment. Fuzzy sets and systems, 114(1), 1-9. https://doi.org/10.1016/S0165-0114(97)00377-1.

[21]. Park, J. H., Park, I. Y., Kwun, Y. C., \& Tan, X. (2011). Extension of the TOPSIS method for decision making problems under interval-valued intuitionistic fuzzy environment. Applied Mathematical Modelling, 35(5), 2544-2556.

https://doi.org/10.1016/j.apm.2010.11.02.

[22]. Kacprzak, D. (2018). Fuzzy TOPSIS method for group decision making. Multiple criteria decision making, 13, 116-132. https://doi.org/10.22367/mcdm.2018.13.07.

[23]. Borovicka, A. (2014). Fuzzy weights estimation method based on the linguistic expression of criteria relevance. Ekonomicka Revue - Central European Review of Economic Issues, 17, 13-23. https://doi.org/10.7327/cerei.2014.03.02.

[24]. Sodhi, B. and Tadinada, P. (2012). A simplified description of Fuzzy TOPSIS. ArXiv, abs/1205.5098, 1-4.

[25]. Mammadova, M. H., \& Jabrayilova, Z. G. (2015). Multi criteria optimization of human resource management problems based on the modified topsis method. Eastern-European Journal of Enterprise Technologies, 2(4), 74. https://doi.org/10.15587/1729-4061.2015.40533. 